\title{
Design of a chitosan-based bio-scaffolding for regenerative medicine: compatibility analysis for cartilage regeneration
}

\author{
Seyed Ali (Behruz) Khaghani ${ }^{1}$, \\ Gunay Akbarova², \\ Gulrukh Dilbazi $^{3}$ \\ ${ }^{1}$ Faculty of Engineering and Informatics, \\ Medical and Healthcare Technology, \\ University of Bradford, BD7 1DP, \\ Bradford, United Kingdom \\ ${ }^{2}$ Department of Genetics and \\ Theory of Evolution, Faculty of Biology, \\ Baku State University, Baku, Azerbaijan \\ ${ }^{3}$ Laboratory of Veterinary Preparations, \\ Veterinary Scientific Research Institute, \\ Baku, Azerbaijan
}

Background. Evaluation of any material that is utilised for clinical applications is essential in order to ensure that it acquires physical, mechanical and biocompatible properties required for its proposed function. Understanding of the conditions that regulate the mechanical and physical characteristics of a material particularly biopolymers is crucial in the field of cell and tissue engineering. The aim of this work is to assemble some polymers and crosslink with each other using $\beta$-glycerophosphate to produce a scaffolding which is suitable for in vitro tissue regeneration.

Materials and methods. The experimental procedures in this project involved the culturing of cells in different suspensions containing control, CSG hydrogel, fibronectin, and hydrogel with fibronectin. The aim of the conducted experiment was to find the cell viability and cytotoxicity analysis of CSG hydrogel, and to study how the cells interact with CSG hydrogel as a possible candidate for articular cartilage repair. Another aim of this work was to find out whether the cells can grow and survive in CSG hydrogel for a period of 24 hours.

Results and conclusions. The results obtained from series of tests proved that CSG3 has the most optimum properties, as it presented the highest viscosity at $37^{\circ} \mathrm{C}$, the highest stability during temperature changes, and an enhanced elastic behaviour at the physiological temperature.

Keywords: Chitosan, hydrogel, $\beta$-glycerophosphate, crosslinking, cell culture

The paper was presented at the "Smart Bio" conference event in Kaunas, 18-20 May 2017

\section{INTRODUCTION}

Articular cartilage provides an almost frictionless surface that none of the artificial constructs have been able to successfully reproduce. Cartilage de-

\footnotetext{
* Corresponding author: E-mail: s.khaghani@bradford.ac.uk
}

generation caused by injuries and congenital abnormalities is a great clinical challenge (Gillogli, Voight, Blachburn, 1998). Damage to the cartilage results in an incomplete wound healing and can be followed by progressive and chronic lesions (Bhosale, Richardson, 2008). Most of the current treatments, including marrow stimulation and 
osteochondral defect substitute, aim at bone marrow stimulation and at the in vivo synthesis of the cartilage. However, each treatment has some substantial limitations and complications such as limited supply, suffering from donor site morbidity, and deficient long-term repair (Jabbari, Khademhosseini 2010; Mouw, Case, Guldberg, Plaas, Levenston, 2005). In order to understand tissue functions, it is important to initially study the structural organization of the tissue and refer to it as it is the main factor directing its properties. In the case of the cartilage, it is highly important that the scaffolding contains the similar characteristics of the native tissue such as material resistance to compressive load and shear stress.

One of the factors that influences the mechanical properties of the tissue is the orientation and arrangement of collagen type II fibril (Moger, Barrett, Bleuet, Bradley, Ellis, Green, Knapp et al., 2007). The fibrils form a 3D network which is embedded in the ECM along with negatively charged GAGs and non-collagenous proteins. This network is maintained and held under tension by proteoglycans (PGs) including chondroitin and keratin sulphate and therefore the tissue is able to withstand great compressive loads and to function as a shock absorber (Mouw, Case, Guldberg, Plaas, Levenston, 2005) and (Jeong, Kim, Bae, 2012). The cartilage repair strategy generally involves a process where the harvested chondrocyte or stem cells are grown in or on artificially generated biocompatible/biodegradable 3D matrices (Ikada, 2006) called scaffolding. The scaffolding provides a condition similar to the body environment for the cells to produce their own extracellular matrix before implantation in the injured area. Prior to implantation, integer mechanical and biochemical testing needs to be conducted to ensure that the scaffolding provides an appropriate condition for cell proliferation, adhesion to the scaffold and migration within pores and most importantly ECM synthesis.

Hydrogels are hydrophilic polymer-based networks that absorb a significant amount of water or physiological fluid, while they maintain their shape (Jeong, Kim, Bae, 2012). Differ- ent types of hydrogels are widely used biomaterials to regenerate cartilage. Thermosensitive hydrogels with sol-gel transition property under different temperatures provide a minimally invasive procedure of cartilage regeneration.

One of the biopolymers for the production of thermosensitive hydrogel with an environment similar to the cartilage is chitosan. Chitosan (CS) is a unique polysaccharide produced from chitin by partial deacetylation which is a suitable biomaterial with its excellent biological properties (Table 1). This type of hydrogel is a solution with a physiological $\mathrm{pH}(7.0-7.4)$ and at room temperature $\left(20-25^{\circ} \mathrm{C}\right)$, but it changes into a gel at body temperature $\left(37^{\circ} \mathrm{C}\right)$.

Table 1. Biocompatible properties of chitosan

\begin{tabular}{cc}
\hline \multicolumn{2}{c}{ Properties of chitosan } \\
\hline Biocompatible & Physiological inertness \\
\hline Biodegradable & Fungistatic \\
\hline Antibacterial & Anticholesteremic \\
\hline Analgetic & Antitumoral \\
\hline Affinity to Proteins & Haemostatic \\
\hline $\begin{array}{c}\text { Crosslinking with } \\
\text { other polymers }\end{array}$ & Mucoadhesive \\
\hline
\end{tabular}

\section{MATERIALS AND METHODS}

Chitosan powder with DD $>95 \%$ and 349,000 molecular weight, z-glycerophosphate disodium salt hydrate ( $\geq 99.0 \%$ titration by HCL), acetic acid, and gelatin (Sigma Aldrich, UK) are utilised during this experiment.

Chitosan solution can be made by dissolving chitosan in organic acids such as acetic, formic, and lactic acids (Rinaudo, Pavlov, Desbrieres, 1999). Acetic acid was selected as it has been reported that it is acidic enough to effectively dissolve chitosan, while a slightly acidic environment is necessary to trigger the antimicrobial and eliciting activities of chitosan (Jeong, Kim, Bae, 2012).

Briefly, nine samples of varying chitosan and gelatin solution were crosslinked with $\beta$-glycerophosphate ( $\beta$-GP), $1 \mathrm{mg} / \mathrm{ml}$ fibronectin (ECM protein) added to support cell adhesion, and their rheological properties were evaluated. 
The three most optimum compositions in terms of viscosity were selected, to these, $5 \mathrm{mmol} \beta$-GP were added to transform the solution to hydrogel.

Preparation of the chitosan solution. Chitosan powder (Sigma Aldrich, UK) was dissolved in $0.2 \mathrm{M}$ acetic acid (Sigma Aldrich, UK) with various concentrations as described below:

$50 \mathrm{ml}$ of $0.2 \mathrm{M}$ acetic acid (AA) was transferred into a $100 \mathrm{ml}$ beaker and stirred at approximately $740 \mathrm{rpm}$ (Romanazzi, Gabler, Margosan, Mackey, Smilanick, 2009). Chitosan (CS) powder was added to the acetic acid while stirring it for six hours to achieve solution with the ratios as shown in Table 2. After dissolving chitosan, a proper amount of gelatin $(G)$ was added to the solution and the stirring continued for another two hours to achieve the desired ratio.

Formation of hydrogel. $\beta$-glycerophosphate $(\beta-G P)$ solution was prepared by dissolving $\beta$-GP powder in deionised water to make $5 \mathrm{mM}$. The crosslinker $\beta$-GP was added dropwise to the chitosan/gelatin solution (CSG) $(2.5 \% \mathrm{v} / \mathrm{v})$ while stirring for 10 minutes at room temperature. Samples were stored at $4^{\circ} \mathrm{C}$ to maintain relatively stable viscosity (Esam, El-hefian, Yahya, 2010). Following the $\mathrm{pH}$ measurement of the hydrogel, further $\beta$-GP was added to the hydrogel to adjust the $\mathrm{pH}$ of the solution from acidic to biological $\mathrm{pH}$ (7.4) (Kim, Son, Kim, Weller, Hanna, 2006). The samples were again stored at $4^{\circ} \mathrm{C}$ for further experiments.

Cell culture test. The growth of cells in the four suspensions with and without fibronectin supplementation were analysed over a 24hour period. $31.7 \times 10^{4}$ cells were encapsulated in each hydrogel, incubated for a minimum of 24 hours at $37^{\circ} \mathrm{C}$, and examined for their viability. The cells were seeded in CSG hydrogel with a $\mathrm{pH}$ of 7.23 and this $\mathrm{pH}$ proved to be well suited for the survival of chondrocyte cells.
Tests of physical and mechanical properties. The Differential Scanning Calorimeter (DSC) Q2000 was used together with the Universal Analysis 2000 Software to explore the effect of heat on the material. The compositions prepared were labelled as CSG1 $(0.20 \mathrm{~g} / \mathrm{ml}$ chitosan, $0.5 \%$ gelatin, $5 \mathrm{mM} \beta$-GP $)$, CSG2 $(0.25 \mathrm{~g} / \mathrm{ml}$ chitosan, $0.5 \%$ gelatin, $5 \mathrm{mM} \beta-\mathrm{GP})$, and CSG3 $(0.30 \mathrm{~g} / \mathrm{ml}$ chitosan, $0.5 \%$ gelatin, $5 \mathrm{mM} \beta-\mathrm{GP}$ ).

The viscosities of hydrogels were recorded at both $25^{\circ} \mathrm{C}$ and $37^{\circ} \mathrm{C}$ using the Anton Paar Physica MCR 301, while the effects of the temperature change were examined via the use of TA Instrument DSC Q2000.

Differential Scanning Calorimeter. Differential scanning calorimetry (DSC) investigates the effects of heat on phase transition of materials and chemical reactions as a function of time and temperature by measuring the difference in the heat flow between the sample and the reference object across the same temperature range which can be expressed as:

$$
\Delta \frac{d H}{d t}=\left(\frac{d H}{d t}\right)_{\text {sample }}-\left(\frac{d H}{d t}\right)_{\text {reference }},
$$

where is $\frac{d H}{d t}$ the heat flow.

Considering that hydrogel will undergo a thermal transition from $\sim 25^{\circ} \mathrm{C}$ to $\sim 37^{\circ} \mathrm{C}$ during its injection into the patient's body, it is important to investigate the effects of the temperature change on the material as that parameter might trigger phase transitions and chemical reactions within the hydrogel network. This information was obtained via the use of TA Instrument Differential Scanning Calorimeter (DSC) Q2000 together with the Universal Analysis 2000 Software (Fig. 1) where the experiment was designed and the measurements were collected and analysed.

Table 2. Chitosan/acetic acid/gelatin samples with various concentrations

\begin{tabular}{|c|c|c|c|c|c|}
\hline \multirow{2}{*}{$\begin{array}{c}\begin{array}{c}\text { Number of } \\
\text { samples prepared }\end{array} \\
3\end{array}$} & \multicolumn{3}{|c|}{$50 \mathrm{ml}$ solution of $\mathrm{CS} / \mathrm{AA}(\mathrm{g} / \mathrm{ml})$} & \multirow{2}{*}{$\begin{array}{c}\text { Amount of gelatin }(\mathrm{g}) \text { added } \\
\text { to } 50 \mathrm{ml} \mathrm{CS/AA} \text { solution }\end{array}$} & \multirow{2}{*}{$\begin{array}{c}\text { Gelatin, \% } \\
0.5 \%\end{array}$} \\
\hline & 0.20 & 0.25 & 0.30 & & \\
\hline 3 & 0.20 & 0.25 & 0.30 & 0.50 & $1.0 \%$ \\
\hline 3 & 0.20 & 0.25 & 0.30 & 0.75 & $1.5 \%$ \\
\hline
\end{tabular}




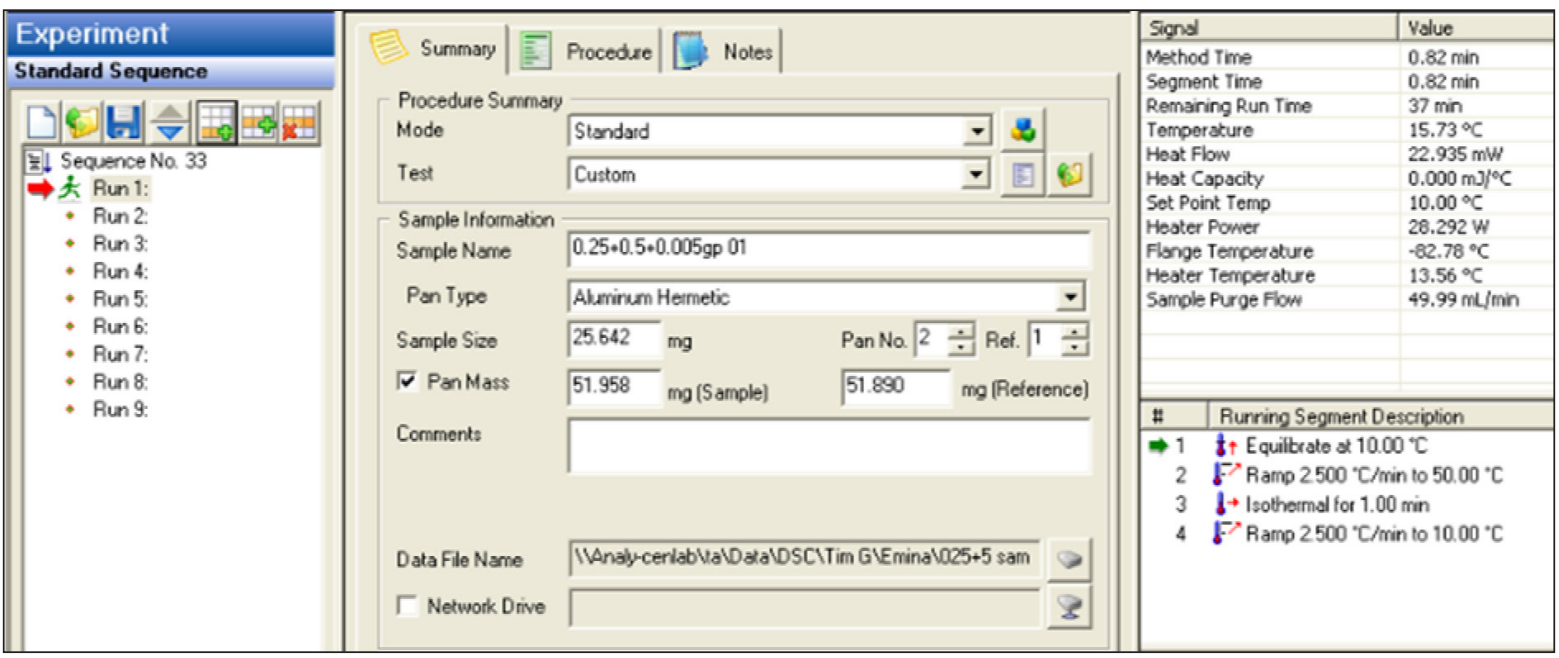

Fig. 1. Universal Analysis 2000 software environment. Program setup

Regarding the design of the experiment, it was decided to run a test cycle of four intervals: (1) equilibration at $10^{\circ} \mathrm{C},(2)$ temperature increase ramp mode at $2.5^{\circ} \mathrm{C} / \mathrm{min}$, (3) isothermal mode for $1 \mathrm{~min}$, and (4) temperature decrease ramp mode at $2.5^{\circ} \mathrm{C} / \mathrm{min}$ (Fig. 1) for each sample. During the equilibration mode, the temperature of the heating block on which the sample was placed was equilibrated at $10^{\circ} \mathrm{C}$ before proceeding on to the first ramp mode at which the temperature increased at the rate of $2.5^{\circ} \mathrm{C} / \mathrm{min}$ from $10^{\circ} \mathrm{C}$ to $50^{\circ} \mathrm{C}$. When $50^{\circ} \mathrm{C}$ was reached, the temperature was kept constant at that point for $1 \mathrm{~min}$ after which a nitrogen cooling system $(50 \mathrm{ml} / \mathrm{min})$ was used to cool down the sample at the $2.5^{\circ} \mathrm{C} / \mathrm{min}$ rate from $50^{\circ} \mathrm{C}$ to $10^{\circ} \mathrm{C}$.

Three samples were prepared from each of three hydrogels crosslinked with $\beta$-GP using hermetic aluminium pans. Each pan was weighted before and after the addition of the material in order to determine the mass of both the pan and the sample. That information was required by the Universal Analysis 2000 Software for the calculation of the heat flow $(\mathrm{W} / \mathrm{g})$, which is expressed as heat flow ( $\mathrm{mW}$ ) over sample mass (mg). The mass of both the sample and the pan is displayed in a table, while the pans containing the material were sealed using a Tzero DSC Sample Encapsulation Press. Both the reference and the sample pans were placed on their corresponding heating blocks automatically by the DSC device. A paired t-test was performed to examine and compare the heat flow between CSG1, 2, and 3 (Table 3).

\section{RESULTS}

Cell culture. The chondrocyte cells were able to survive in CSG hydrogel for over 24 hours. This is evidence that CSG hydrogel is cellviable and cells can grow successfully in CSG hydrogel. The number of cells encapsulated inside CSG hydrogel more than tripled over the 24-hour period. It also confirms that CSG hydrogel is not cytotoxic but has an environment that is suitable for cell growth instead. The presence of fibronectin in CSG hydrogel further increased the growth of the cells and the formation of the ECM (Table 4 and Fig. 2).

Table 4 shows cell growth over a period of 24 hours. From the control reading all suspensions had the same number of cells; the initial number of cells in each suspension was $31.7 \times 10^{4}$. The addition of fibronectin increased the cell growth in CSG hydrogel.

The three-dimensional structure of CSG hydrogel provides a better environment for the growth of cells in comparison to the control monolayer cell culture. After a 24-hour period the cells in the control increased from $31.7 \times 10^{4}$ to $129 \times 10^{4}$, the cells in CSG hydrogel showed a greater increase from $31.7 \times 10^{4}$ to $195 \times 10^{4}$. This greater increase of cells in CSG 
Table 3. Paired t-test at 95\% CI regarding the heat flow of CSG1, CSG2, and CSG3

\begin{tabular}{|c|c|c|c|c|c|c|}
\hline Sample & Sample size & Mean & SD & SE mean & $t$-value & $P$-value \\
\hline CSG1 & 9852 & -0.00694 & 0.14587 & 0.00147 & \multirow{3}{*}{145.65} & \multirow{3}{*}{0.000} \\
\hline CSG2 & 9852 & -0.02144 & 0.14542 & 0.00147 & & \\
\hline Difference & 9852 & 0.014496 & 0.009879 & 0.00010 & & \\
\hline CSG1 & 9852 & -0.00694 & 0.14587 & 0.00147 & \multirow{3}{*}{-3.08} & \multirow{3}{*}{0.002} \\
\hline CSG3 & 9852 & -0.00549 & 0.19241 & 0.00194 & & \\
\hline Difference & 9852 & -0.001453 & 0.046755 & 0.000471 & & \\
\hline CSG2 & 9852 & -0.02144 & 0.14542 & 0.00147 & \multirow{3}{*}{-32.77} & \multirow{3}{*}{0.000} \\
\hline CSG3 & 9852 & -0.00549 & 0.19241 & 0.00194 & & \\
\hline Difference & 9852 & -0.015949 & 0.48307 & 0.000487 & & \\
\hline
\end{tabular}

Table 4. Number of cells in the suspensions

\begin{tabular}{c|c|c|c|c}
\hline \multirow{2}{*}{ Time (hours) } & \multicolumn{4}{|c}{ Number of Cells $\left(\times \mathbf{1 0} \mathbf{0}^{\mathbf{4}}\right)$} \\
\cline { 2 - 6 } & Control & CSG hydrogel & Fibronectin & CSG hydrogel \& fibronectin \\
\hline 0 & 31.7 & 31.7 & 31.7 & 31.7 \\
\hline 1 & 64 & 67 & 87 & 112 \\
\hline 24 & 129 & 195 & 227 & 233 \\
\hline
\end{tabular}

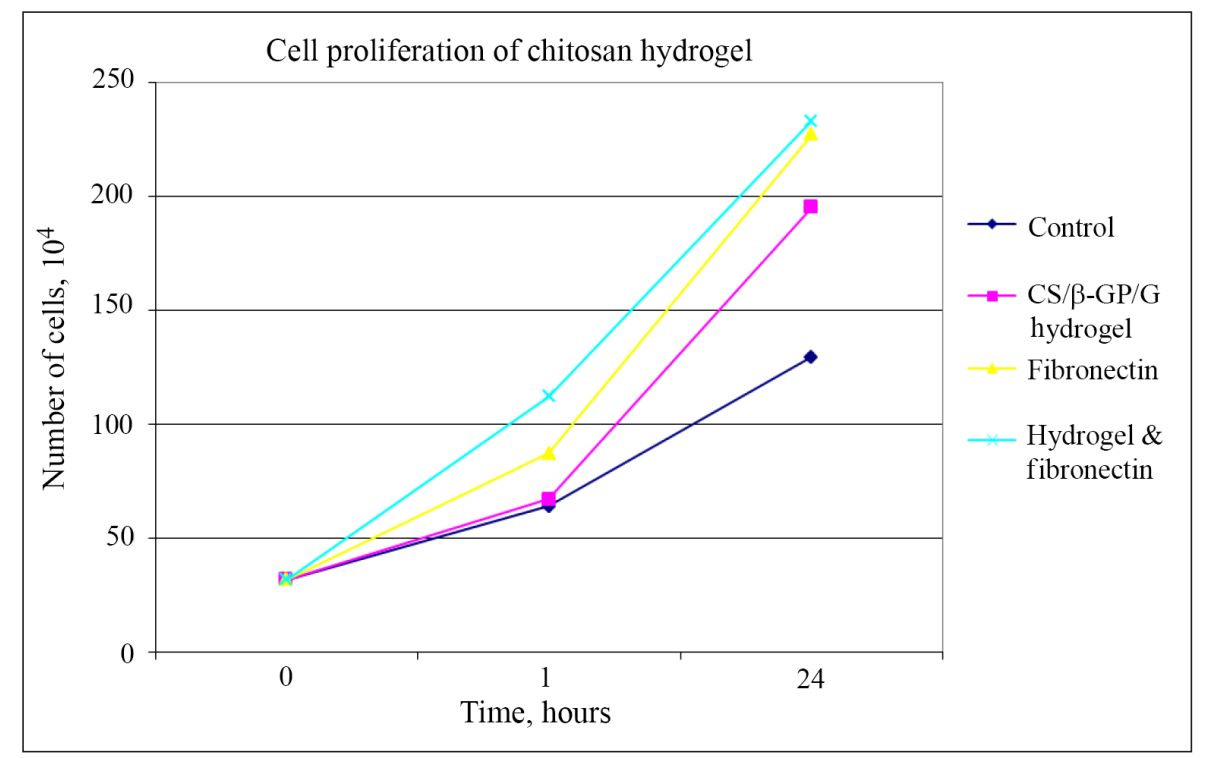

Fig. 2. The figure shows the growth of chondrocyte cells in the suspensions over a 24-hour period, with an initial reading after seeding the cells and after one hour

hydrogel shows that at a $\mathrm{pH}$ of 7.23 CSG hydrogel provides a better environment for cell proliferation. 2D-culture system has been believed to be best suited for the proliferation of cells, but this experiment has shown that the environment provided by CSG hydrogel is better suited for the growth for chondrocyte cells.
The addition of fibronectin to CSG hydrogel further increased the growth of cells. The chondrocyte cells in the suspension containing $180 \mu \mathrm{l}$ of CSG hydrogel with $20 \mu \mathrm{l}$ of fibronectin increased from $31.7 \times 10^{4}$ to $233 \times 10^{4}$ over a 24 -hour period. The experiment has shown that fibronectin has a substantial effect on the cell growth. 
T-test. T-tests can be used to assess the presence of any significance in the difference between the means of two groups. A t-test was conducted to assess whether the difference in the number of cells was significant in the control and in CSG hydrogel after one hour of growth (Fig. 3). Before carrying out the t-test, a graph was created using Excel to identify whether there was a significant difference in the data collected for the cell number in the first hour of culturing.

A paired t-test was further conducted on the control and CSG hydrogel after one hour to assess whether there was any significance in the difference between the mean values of the control and CSG hydrogel after one hour. For this t-test the risk level was set at 0.05, which is the general rule of thumb value. The $t-$ test showed a $P$ value of 0.222 , and this value being greater than 0.05 indicated that there was no significance in the difference between the sets of data (Table 5).

The graph shows the mean values of the data for the cell number in the control and CSG hydrogel suspension after one hour. A graph with \pm 1 standard deviation (S.D.) was plotted to prove the difference in the data. The $( \pm 1)$ S.D. of the control overlaps with the $( \pm 1)$ S.D. of CSG hydrogel on the y-axis. This indicates that there is no significant difference between the two sets of data.

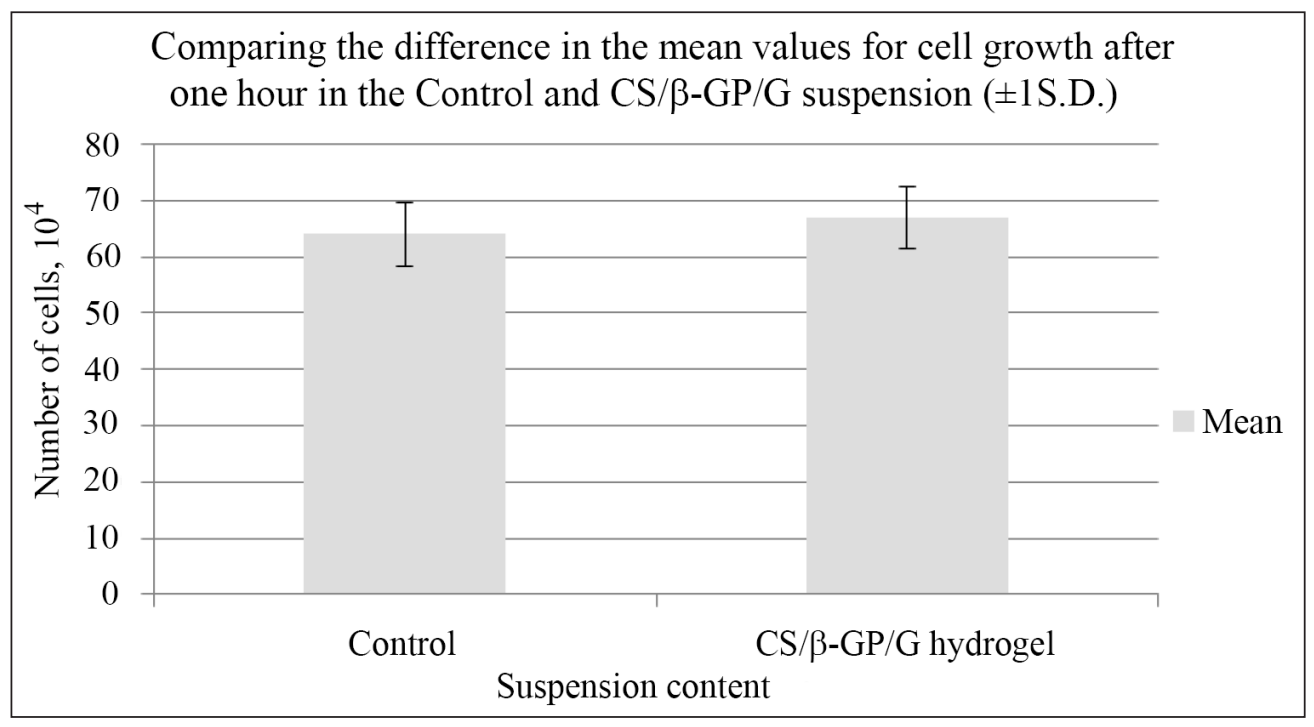

Fig. 3. Graph comparing the means of the control and CSG hydrogel and the S.D. for the cell count after one hour

Table 5. The values for the paired t-test conducted on the control and CSG hydrogel, for the cell count after 1 hour

\begin{tabular}{|c|c|c|}
\hline \multicolumn{2}{|l|}{ t-Test: Paired two samples for means } & CSG \\
\hline & Control & 67 \\
\hline Mean & 64 & 30 \\
\hline Variance & 32.8 & 6 \\
\hline Observations & 6 & \\
\hline Hypothesized mean difference & 0 & \\
\hline Degree of freedom & 5 & \\
\hline$t$ stat & -0.827815914 & \\
\hline$P(T \leq t)$ one-tail & 0.222737208 & \\
\hline
\end{tabular}


Physical and mechanical test. Three most optimum hydrogels were selected for analysis of their mechanical properties. These three samples presented the lowest viscosity at room temperature $\left(25^{\circ} \mathrm{C}\right)$ and the highest at body temperature $\left(37^{\circ} \mathrm{C}\right)$, compared to the rest of the samples. The data obtained from these hydrogels at room temperature $\left(25^{\circ} \mathrm{C}\right)$ and body temperature $37^{\circ} \mathrm{C}$ are shown in Tables 6 and 7 , and in Fig. 4.

Differential Scanning Calorimeter. Samples CSG1, CSG2 and CSG3 were tested using the DSC within the temperature range of $1^{\circ} \mathrm{C}$ to $50^{\circ} \mathrm{C}$ in order to monitor heat effects on the behaviour of hydrogels. Viewing the DSC output in Fig. 5, no significant structural changes were observed. The heat flow remained constant throughout the process of heating and cooling, without indicating any change of phase, such as an exothermic or en- dothermic reaction. Consequently, it is possible to argue that the hydrogels present a stable behaviour across the selected temperature range $\left(10-50^{\circ} \mathrm{C}\right)$ and thus they are safe to be used in biomedical applications.

\section{DISCUSSION}

The results showed that chitosan-based hydrogel (CSG) supplemented with $0.5 \%$ gelatin as copolymer and crosslinked with $\beta$-glycerophosphate ( $\beta$-GP) was able to provide an environment encouraging cell growth. The adjustment of the $\mathrm{pH}$ of CSG hydrogel to 7.23 proved to be non-cytotoxic to the cells. Over the 24-hour period the cells managed to survive and proliferate inside CSG hydrogel. In the first hour the cell growth in the CSG hydrogel suspension was greater than in that of the control suspension.

Table 6. Paired t-test regarding the viscosity of CSG1, CSG2, and CSG3 at $25^{\circ} \mathrm{C}$

\begin{tabular}{|c|c|c|c|c|c|c|}
\hline Sample & Sample Size & Mean & SD & SE mean & $t$-value & $p$-value \\
\hline CSG1 & 25 & 0.033390 & 0.011870 & 0.002370 & \multirow[t]{3}{*}{6.75} & \multirow[t]{3}{*}{0.000} \\
\hline CSG2 & 25 & 0.029400 & 0.009270 & 0.001850 & & \\
\hline Difference & 25 & 0.003996 & 0.002959 & 0.000592 & & \\
\hline CSG1 & 25 & 0.033390 & 0.011870 & 0.002370 & \multirow[t]{3}{*}{-10.16} & \multirow[t]{3}{*}{0.000} \\
\hline CSG3 & 25 & 0.076240 & 0.032440 & 0.006490 & & \\
\hline Difference & 25 & -0.04285 & 0.021090 & 0.004220 & & \\
\hline CSG2 & 25 & 0.02940 & 0.009270 & 0.001850 & \multirow[t]{3}{*}{-10.05} & \multirow[t]{3}{*}{0.000} \\
\hline CSG3 & 25 & 0.07624 & 0.032440 & 0.006490 & & \\
\hline Difference & 25 & -0.04684 & 0.023310 & 0.004660 & & \\
\hline
\end{tabular}

Table 7. Paired t-test regarding the viscosity of CSG1, CSG2 and CSG3 at $37^{\circ} \mathrm{C}$

\begin{tabular}{|c|c|c|c|c|c|c|}
\hline Sample & Sample size & Mean & SD & SE mean & $t$-value & $p$-value \\
\hline CSG1 & 25 & 0.019158 & 0.004167 & 0.000833 & \multirow{3}{*}{15.55} & \multirow{3}{*}{0.000} \\
\hline CSG2 & 25 & 0.015737 & 0.003226 & 0.000645 & & \\
\hline Difference & 25 & 0.003420 & 0.001100 & 0.000220 & & \\
\hline CSG1 & 25 & 0.019158 & 0.004167 & 0.000833 & \multirow{3}{*}{-12.44} & \multirow{3}{*}{0.000} \\
\hline CSG3 & 25 & 0.042880 & 0.013610 & 0.002720 & & \\
\hline Difference & 25 & -0.02372 & 0.009530 & 0.001910 & & \\
\hline CSG2 & 25 & 0.015737 & 0.003226 & 0.000645 & \multirow{3}{*}{-12.96} & \multirow{3}{*}{0.000} \\
\hline CSG3 & 25 & 0.042880 & 0.013610 & 0.002720 & & \\
\hline Difference & 25 & -0.02714 & 0.010470 & 0.00209 & & \\
\hline
\end{tabular}




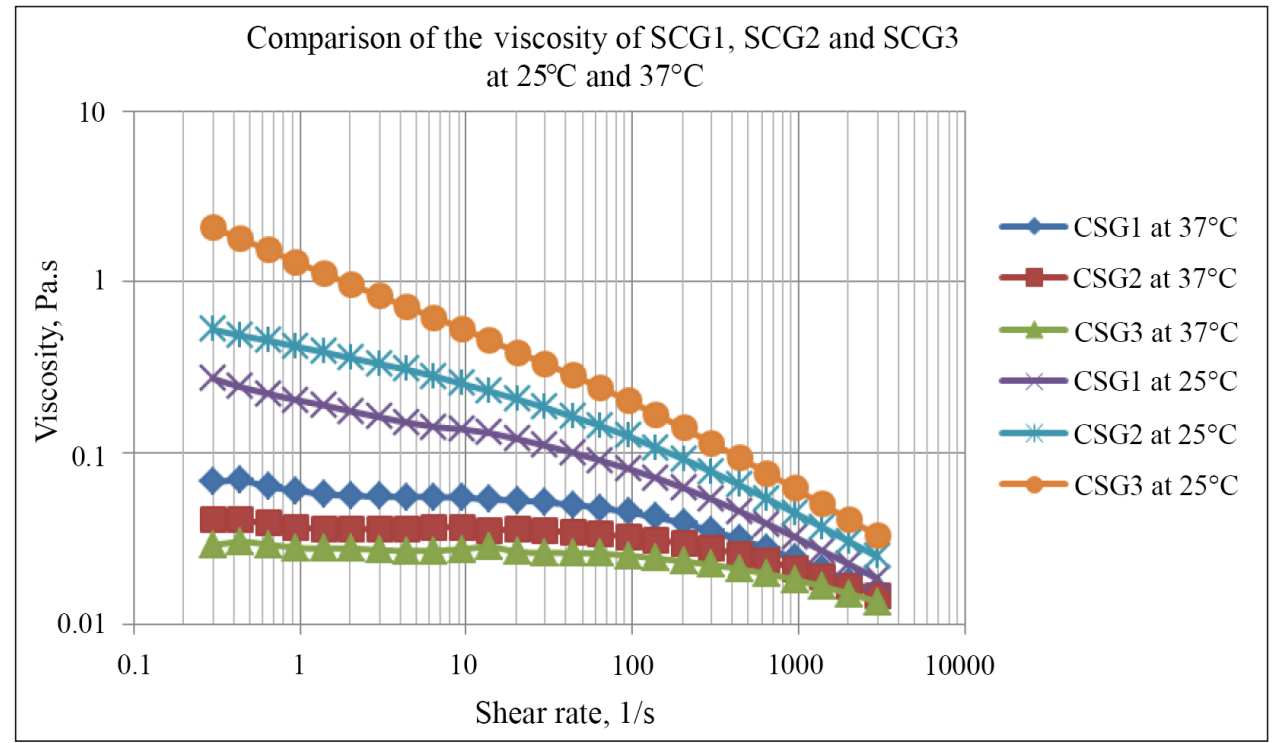

Fig. 4. Average shear viscosity and shear stress for CSG1, CSG2, and $\mathrm{CSG} 3$ at $25^{\circ} \mathrm{C}$ and $37^{\circ} \mathrm{C}$

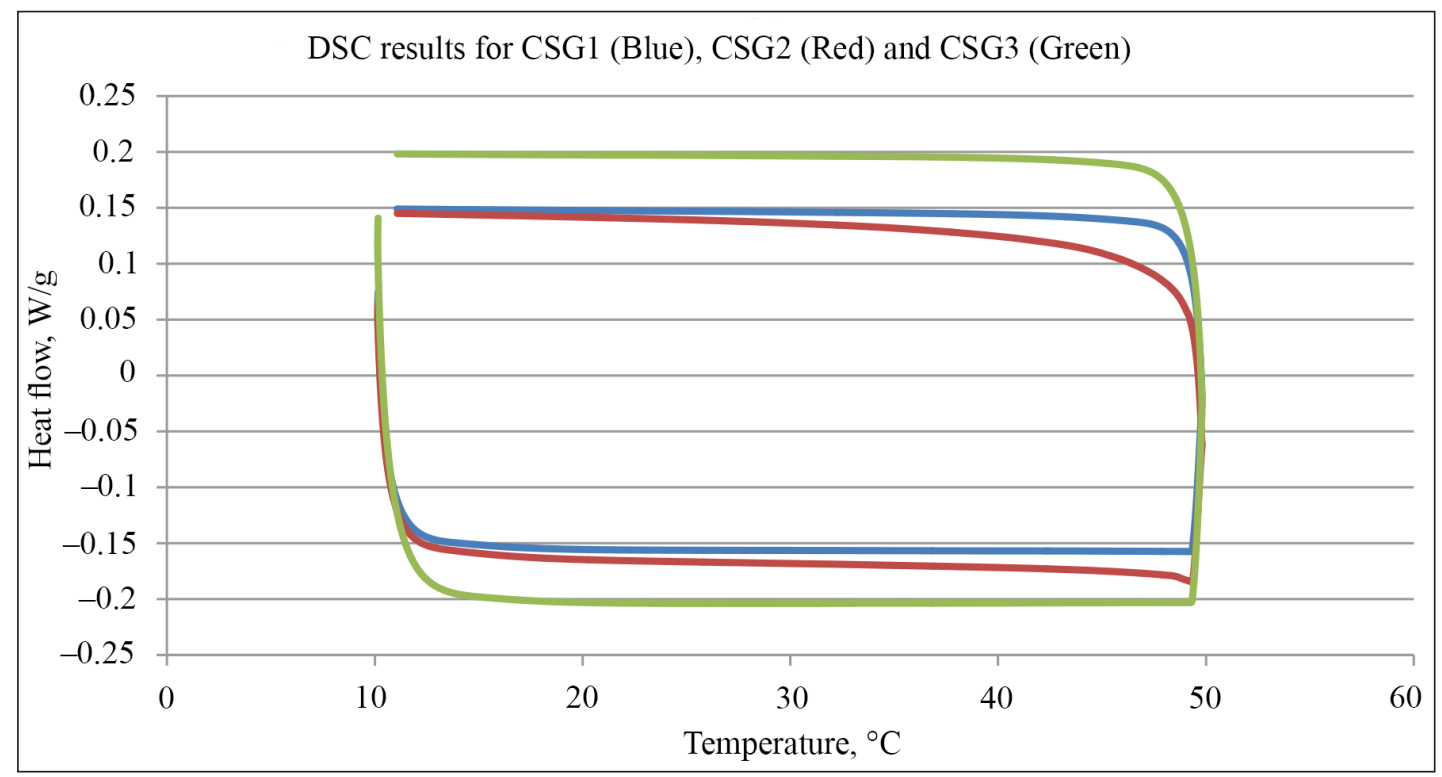

Fig. 5. Mean values of the heat flow (W/g) for CSG1 with $0.20 \mathrm{~g} / \mathrm{ml}$ chitosan/acetic acid, for SCG2 with $0.25 \mathrm{~g} / \mathrm{ml}$ chitosan/acetic acid, and for SCG3 with $0.30 \mathrm{~g} / \mathrm{ml}$ chitosan/acetic acid. All three samples were supplemented with $0.5 \%$ gelatin and crosslinked with $5 \mathrm{mM} \beta$-GP

$\beta$-glycerophosphate provides stability to the behaviour of hydrogel as proven by their Newtonian flow below $100 \mathrm{~s}-1$ at $25^{\circ} \mathrm{C}$ and $37^{\circ} \mathrm{C}$. At $37^{\circ} \mathrm{C}$, the hydrogen bonds decrease leading to the formation of hydrophobic interactions that hinder the reduction of viscosity (Romanazzi, Gabler, Margosan, Mackey, Smilanick, 2009). Viewing the DSC output, the heat flow remains constant indicating no phase change. Consequently, it is possible to argue that hydrogels present a stable behaviour across $10-50^{\circ} \mathrm{C}$ and thus they are safe to be used in biomedical applications. Finally, the hydrogels showed an elastic behaviour during heating $\left(10-50^{\circ} \mathrm{C}\right)$ and cooling $\left(50-10^{\circ} \mathrm{C}\right)$ as $\mathrm{G}^{\prime}>\mathrm{G}^{\prime \prime}$, while, as the chitosan content increases, both G' and G" decrease due to the nature of the internal crosslinking of hydrogels. The damping 
coefficient reduction suggested an enhanced elasticity, particularly between $26^{\circ} \mathrm{C}$ and $37^{\circ} \mathrm{C}$. The increase in the elasticity is probably related to specific interactions formed in the presence of $\beta$-GP (Chenite, Chaput, Wang, Combes, Buschmann, Hoemann, Leroux, Atkinson, Binette, Selmani, 2000).

The adhesive properties of fibronectin had the effect of enhancing cell growth (Moger et al., 2007). Growing the cells in the threedimensional structure of CSG hydrogel allowed the chondrocyte cells to grow in different layers. The cell growth was not limited to a single plane like that of the monolayer cell culture, and the growth of the chondrocyte cells in CSG hydrogel was larger. The proliferative rate of the cells in CSG hydrogel was also greater than that of the monolayer cell culture; in the first hour of culturing the cell growth in CSG hydrogel was greater than the control monolayer culture and this result shows that CSG hydrogel is able to provide a better environment for cell proliferation. However, the conducted t-test showed that the difference was not significant: the cells in CSG hydrogel after the 24 hours were greater in the number in comparison to the number of cells in the control suspension. The ability of CSG hydrogel to retain the phenotype was impossible to be analysed due to the lack of equipment. However, when viewed under the light-emitting microscope, it was evident that CSG hydrogel was better at retaining the spherical morphology of chondrocyte cells.

Received 17 March 2017 Accepted 9 June 2017

\section{References}

1. Gillogli SD, Voight M, Blachburn T. Treatment of articular cartilage defects of the knee with autologous chondrocyte implantation. J Orthop Sports Phys Ther. 1998; 28: 241-51.

2. Bhosale A, Richardson J. Articular cartilage: structure, injuries and review of management. Br. Med. Bull. 2008; 87: 77-95.
3. Jabbari E, Khademhosseini A. Biologicallyresponsive hybrid biomaterials: a reference for material scientists and bioengineers. World Scientific Publishing Co: 2010.

4. Moger CJ, Barrett R, Bleuet P, Bradley DA, Ellis RE, Green EM, Knapp KM, Muthuvelu P, Winlove CP. Regional variations of collagen orientation in normal and diseased articular cartilage and subchondral bone determined using small angle X-ray scattering (SAXS). Osteoarthr Cartil. 2007; 15: 682-7.

5. Mouw JK1, Case ND, Guldberg RE, Plaas AH, Levenston ME. Variations in matrix composition and gag fine structure among scaffolds for cartilage tissue engineering. Osteoarthr Cartil. 2005; 13: 828-36.

6. Yoshito Ikada. Tissue engineering: fundamental and applications, 1st edition. Ikada: Y. Academic Press; 2006. 1: 490.

7. Rinaudo M, Pavlov G, Desbrieres J. Influence of acetic acid concentration on the solubilization of chitosan. Polymer. 1999; 40: 7029-32.

8. Jeong B, Kim SW, Bae YH. Thermosensitive sol-gel reversible hydrogels. Adv Drug Deliv Rev. 2012; 64: 154-162.

9. Romanazzi G, Gabler FM, Margosan D, Mackey BE, Smilanick JL. Effect of chitosan dissolved in different acids on its ability to control postharvest gray mold of table grape. The American Phytopathological Society. 2009; 99: 1028-36.

10. El-hefian EA, Abdul H. Yahaya AH. Rheological study of chitosan and its blends: an overview. Maejo Int. J. Sci. Technol. 2010; 4: 210-220.

11. Kim KM, Son JH, Kim SK, Weller CL, Hanna MA. Properties of chitosan films as a function of $\mathrm{pH}$ and solvent type. J Food Sci. 2006; 71: 119-24.

12. Chenite A, Chaput C, Wang D, Combes C, Buschmann MD, Hoemann CD, Leroux JC, Atkinson BL, Binette F, Selmani A. Novel injectable neutral solutions of chitosan form biodegradable gels in situ. Biomaterials. 2000; 21: 2155-61. 
Seyed Ali (Behruz) Khaghani, Gunay Akbarova, Gulrukh Dilbazi

BIOKARKASŲ PROJEKTAVIMAS CHITOZANO PAGRINDU REGENERACINEI MEDICINAI: KREMZLE்S REGENERACIJOS ANALIZE்

\section{Santrauka}

Bet kokios medžiagos, naudojamos klinikinèms reikmèms, analizė yra būtina norint užtikrinti jos fizinių, mechaninių ir biologinių savybių suderinamumą, reikalingą tam tikrai funkcijai. Žinojimas sąlygų, kurios reguliuoja mechanines ir fizines medžiagos savybes, ypač biopolimerų, yra labai svarbus ląstelių ir audinių inžinerijai. Šio tyrimo tikslas - sukonstruoti polimerus ir juos sujungti tarpusavyje naudojant $\beta$-glicerofosfatą, kad būtų pagamintas karkasas, tinkamas audinių regeneraci- jai in vitro. Eksperimento procesai apèmė skirtingos sudèties suspensijos ląstelių kultūras: kontrolè, CSG hidrogelis, fibronektinas, hidrogelis su fibronektinu. Eksperimentu siekta nustatyti ląstelių gyvybingumą CSG hidrogelyje, jų sąveiką su CSG hidrogeliu, ląstelių išgyvenamumą 24 valandas CSG hidrogelyje, CSG hidrogelio citotoksiškumą, taip pat nustatyti, ar jis gali būti naudojamas ląstelių auginimui in vivo pažeistos sąnarinès kremzlès vietoje. Tyrimo rezultatai rodo, kad CSG3 pasižymi optimaliausiomis savybėmis - sudaro didžiausią klampumą $37^{\circ} \mathrm{C}$ temperatūroje, labiausiai stabilus keičiantis temperatūrai, elastingesnis fiziologinès temperatūros sąlygomis.

Raktažodžiai: chitozanas, hidrogelis, $\beta$-glicerofosfatas, sujungimas, ląstelių kultūra 